\title{
Sewage Treatment In Salem District
}

\author{
T.Subramani ${ }^{1}$, D.Porkodi ${ }^{2}$, J.Jayalakshmi $^{3}$ \\ ${ }^{I}$ Professor \& Dean, Department of Civil Engineering, VMKV Engg. College, \\ Vinayaka Missions University,Salem, India \\ ${ }^{2} P G$ Student of Environmental Engineering, Department of Civil Engineering, \\ VMKV Engg. College, Vinayaka Missions University, Salem, India \\ ${ }^{3} P G$ Student of Structural Engineering, Department of Civil Engineering, \\ VMKV Engg. College, Vinayaka Missions University, Salem, India
}

\begin{abstract}
Sewage treatment is the process of removing contaminants from wastewater and household sewage, both runoff(effluents), domestic, commercial and institutional. It includes physical, chemical, and biological processes to remove physical, chemical and biological contaminants. Its objective is to produce an environmentally safe fluid waste stream (or treated effluent) and a solid waste (or treated sludge) suitable for disposal or reuse (usually as farm fertilizer). Using advanced technology it is now possible to re-use sewage effluent for drinking water, although Singapore is the only country to implement such technology on a production scale in its production of new water. We consider wastewater treatment as water use because it is so interconnected with the other uses of water. Much of the water used by homes, industries, and businesses must be treated before it is released back to the environment. If the term "wastewater treatment" is confusing to you, you might think of it as "sewage treatment." Nature has an amazing ability to cope with small amounts of water wastes and pollution, but it would be overwhelmed if we didn't treat the billions of gallons of wastewater and sewage produced every day before releasing it back to the environment. Treatment plants reduce pollutants in wastewater to a level nature can handle. Wastewater is used water. It includes substances such as human waste, food scraps, oils, soaps and chemicals. In homes, this includes water from sinks, showers, bathtubs, toilets, washing machines and dishwashers. Businesses and industries also contribute their share of used water that must be cleaned. Wastewater also includes storm runoff. Although some people assume that the rain that runs down the street during a storm is fairly clean, it isn't. Harmful substances that wash off roads, parking lots, and rooftops can harm our rivers and lakes.
\end{abstract}

KEYWORDS: Sewage Treatment, Salem District,Environmental Management Plan,

\section{INTRODUCTION}

Water Supply, sewerage and sanitation are not only the basic necessities of life, they are also crucial for achieving the goal of "Health for All". Increased sanitation coverage is directly linked to improvement of health status. Water Supply is perhaps the most important and basic need that has to be provided with reliability, sustainability and affordability. In a water starved State like Tamil Nadu, which depends largely on seasonal rainfall, the provision of drinking water to the population acquires even more significance. With successive governments focusing on the need to improve the quality of life, water supply coupled with sanitation is essential in order to facilitate the citizens to lead a healthy and productive life. Salem Municipality was formed in 1998 and later the Centurion Municipality was declared as the Salem city municipal corporation from 1.6.1994 under Salem Corporation Act. The Salem City Municipal Council celebrated its Centenary in 1966.

\subsection{WATER SUPPLY}

\section{OBJECTIVES TARGETS AND STRATEGIES}

- To increase the coverage of water supply in all towns to achieve the norms for per capita supply ensuring quality of the water.

- To ensure reliability of supply of water for 24 hours in towns in a phased manner.

- To install desalination plants in all coastal towns with appropriate subsidy.

- To increase the norms levels for per capita in line with JNNURM norms.

- To create small water supply undertakings similar to electrical undertakings run earlier by local bodies (now merged with the EB) under the management and supervision of the urban local bodies and entrust them under qualified professional management.

- To implement HRD programs aiming at capacity building for operating the water supply schemes by Urban Local Bodies (ULBs). 
- To avoid physical losses, zoning of distribution system and leak detection study should be carried out periodically as a preventive measure to arrest the unaccounted water.

- To encourage innovative and cost effective technologies in the implementation and administration of water supply schemes.

\subsection{Sewerage And Sanitation}

- Integration of sanitation and sewerage schemes with water supply so that it is given adequate priority during the Plan period.

- Treating of wastewater from storm water drains and industrial effluents before they enter the watercourses.

- Adoption of innovative and alternate technologies for safe disposal, recycling and reuse of waste water wherever possible.

\subsection{Need Of Sewerage Scheme}

Salem is also an important business center in Tamil Nadu. A number of textile industries, Sago Industries and some Major Industrial units such as the integrated Salem steel plant, burn and Co., Dalmia Magnesite Ltd., Tamil Nadu Magnesite Ltd., are located here. Salem is also famous for body building for Lorries, trucks and buses. Salem district is also having rich mineral deposits such as Magnetite, Bauxite, Iron ore and Limestone. An Underground sewerage scheme has been proposed for the City and funded by World Bank. Apart from the collection system and restoration work, it is proposed to construct individual sewage treatment plant for each Zone as no suitable site was available for the construction of a Common Sewage Treatment Plant.

\subsection{Environmental Management Plan:}

The Environmental Management Plan is derived for construction and operational stage of the project. The green belt development plan and the funds for environmental protection measures along with Post Project Monitoring Plan is also given in the EMP. The entire system is designed with minimum impacts on the environment. Any impacts that may be generated will be prevented at the source. In addition, the following are added. Green belt was developed in available area all around the site to minimize noise and odor. All noise producing equipments will be placed in acoustic hoods to prevent noise pollution. Control of vibrations will be done at the source. The treated sewage will be within prescribed limits of TNPCB and finally drained out of the site. Identification, estimation/quantification of possible impacts over baseline status of water quality, biodiversity, air quality, noise levels and soil profile at the proposed locations during the month of May 2013, reveals that:

[1] The proposed site is free of pollution sources.

[2] There are no critical habitats in the vicinity of the project locations.

[3] The project does not require clearing of any trees.

[4] There is no endemic and rare floral species are identified in the study area

[5] The aquatic environment will not have direct negative impact

[6] Better housing and sanitation facilities for the local residents of the municipality.

Environmental Management Plan will be exercised at design stage, construction stage and operational stage to meet all the consent norms of TNPCB With their expertise, experience, commitment and dedication, Salem City Municipal Corporation along with M/s. Subaya Construction Company limited, Chennai, the contractors for this project, will Design, Construct, Commission and Operate the 35 MLD capacity Sewage Treatment Plant (STP) with modern technology at Mankuttai, Bodinaickenpatti village in Salem Municipality of Salem district in Tamil Nadu.

\section{PROJECT PROFILE}

Salem is a Selection grade municipality and the 'District headquarters for Salem district. The town is spread over an area of $94 \mathrm{~km} 2$. It is the largest urban centre in the district and is about $340 \mathrm{~km}$ south west of Chennai.Salem is located in the north central part of the state, about 340 kilometres (211 mi) southwest of state capital, Chennai. It is the fifth Municipal Corporation and Urban agglomeration in Tamil Nadu after Chennai, Coimbatore, Madurai and Tiruchirappalli. An Underground sewerage scheme has been formulated for the town and the Collection system works are in progress. It is proposed to provide Sewage Treatment Plants to treat the sewage of the town. It is proposed to convey the sewage to the STP site by means of UGSS. The treated effluents from the Sewage Treatment Plant are proposed to be let into the nearby canal which carries the treated water to the Thirumanimutharu River. Salem City Municipal Corporation has under taken the task of Designing, providing, construction, erection and commissioning, start up and performance trial run for 6 months followed 
by 5 years of O \& M of 35.0 MLD capacity Sewage Treatment Plant (STP) with modern technology at Mankuttai, Bodinaickenpatti village in Salem Municipality of Salem district in Tamil Nadu .

\subsection{Primary Treatment}

\section{DESCRIPTION OF THE PROCESS - SEWAGE}

$>$ The Raw Sewage through underground Collection conveyance gets collected in the Collection Well having retention of 10 mints. Considering the Peak flow.

$>$ From the Collection Well the Raw sewage is pumped into the Screening Chamber with the help of Submersible Non Clog Pumps for the removal of Floating particles.

$>$ The outlet of the Screening chamber flows into Detriter tanks for the removal of Sand, Grit etc.(Fig.4.1)

$>$ The outlet of the detriter flows into the aeration tank for further treatment.

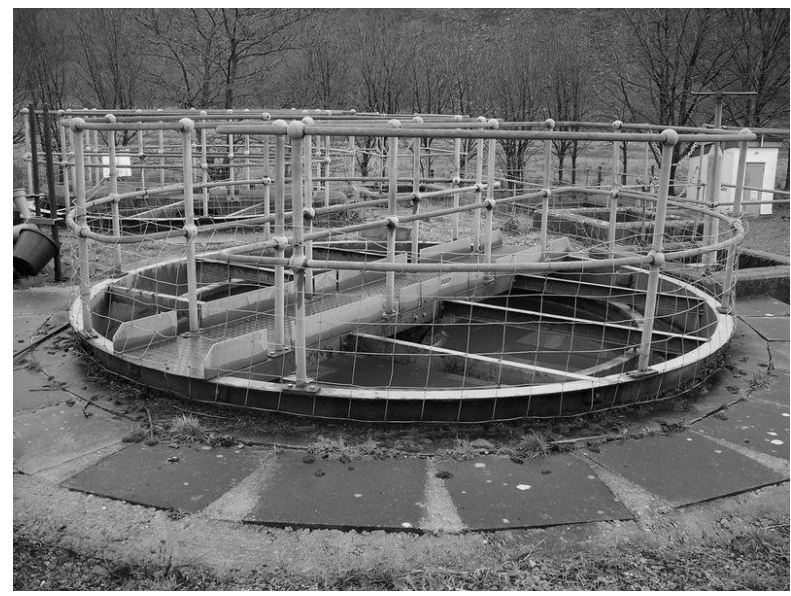

Fig no.4.1 Primary Sedimentation Tank

\subsection{Secondary Treatment}

$>$ In the aeration tank the air will be supplied through Positive Displacement Air Blower for degradation of organic impurities/pollutants by microorganisms.

$>$ The wastewater along with Bio mass will flow by gravity into the Secondary Clarifier tank for Solid-Liquid Separation and re-circulation of solids to the aeration tank.

$>\quad \square$ The Biomass from the bottom of the Secondary Clarifier tank will be transferred by means of an pump to maintain the desired Mixed Liquor Suspended Solids (MLSS) concentration of 6,000 - $8000 \mathrm{mg} / \mathrm{l}$.

$>$ The excess bio mass shall be pumped into Sludge Thickener for thickening the Sludge.

$>$ The thickened Sludge shall be pumped into the Centrifuge for Dewatering.

$>$ Supernatant of the Sludge Thickener is pumped back into the Aeration Tank.

$>$ The supernatant from the Secondary Clarifier tank shall flow by gravity into the Chlorine Contact Tank for Disinfection and disposed though the Out Fall Chamber meeting the standards for disposal.

\subsection{The Disposal of Treated Sludge}

The treated sludge is taken to the site which has been identified by Salem Municipal Corporation. The disposal of grits, screened particles will be collected and removed regularly. The entire system has been designed to treat an immediate flow of 35 MLD while keeping head space for an increase in the population and wastewater of up to a total of 45 MLD. Future expansion spaces for ultimate capacity are provided for aeration tanks and secondary clarifiers as shown in Fig. The future expansion area for Aeration tank I and Aeration tank II will be $81 \mathrm{~m} 2$ and $64 \mathrm{~m} 2$. An area of $226 \mathrm{~m} 2$ has been provided for Secondary clarifier expansion. All the units will be having access from the internal roads. The tanks in the proposed design will be provided with a walkway platform for both inspection and maintenance purposes. To ensure smooth operation of the treatment system during emergencies and maintenance, the system is designed with appropriate bypass arrangement for continuous treatment. By pass arrangements will be provided from the outlet of grit chamber to divert any flooded water to avoid any disturbance to the operation of the plant during any emergency. The plant is designed to withstand any low flow of sewage by controlling the raw sewage pumping and the major units are designed with a stand by tank to treat the wastewater to meet the PCB standards. 


\subsection{Description Of Environment}

The present environmental status of the proposed project has been studied covering $1 \mathrm{Km}$ radius and presented in this chapter.(Table.4.1) It is necessary to know the present quality of the environment with respect to the various aspects considered under impact identification. These factors include air, water, noise, soil, meteorology, and land use, socio-economic and demographic pattern. For this purpose, a monitoring schedule was chalked out covering for a month of the year during May ' 11 to generate baseline data on ambient air quality, quality of ground water / surface water, soil, ambient noise and meteorological parameters like temperature, humidity, wind speed and direction, cloud cover, rainfall etc.(Table.4.2) The baseline data collection on socio-economic and demographic factors, land use pattern, forests, geology, soil and agriculture resources etc. were carried out thoroughly by field survey and secondary data has been collected from the State Government authorities.(Fig.4.2)

Table.4.1 Environmental Sensitive Areas as per TNUDF

\begin{tabular}{|c|l|c|}
\hline Sl. No & \multicolumn{1}{|c|}{ Areas } & Name \\
\hline 1 & National Park & Nil \\
\hline 2 & $\begin{array}{l}\text { Sanctuary / Tiger Reserve / Elephant / } \\
\text { any } \\
\text { other Reserve }\end{array}$ & Nil \\
\hline 3 & Core Zone of Biosphere Reserve & Nil \\
\hline 4 & Habitant for Mitigatory Birds & Nil \\
\hline 5 & $\begin{array}{l}\text { Archaeological Sites } \\
\text { i) Notified } \\
\text { ii) Others }\end{array}$ & Nil \\
\hline 6 & Major Water Bodies & Nil \\
\hline 7 & Defense Installation & Nil \\
\hline 8 & Airports & SH7 (147 mts. from site) \\
\hline 9 & Railway Lines & Hosur to Kanyakumari \\
\hline 10 & National Highways & $\begin{array}{c}\text { SH159 (42 mts. from site) } \\
\text { Palpatti to Suramangalam Rd }\end{array}$ \\
\hline 11 & State Highways & Nil \\
\hline 12 & Schools / Colleges & Nil \\
\hline 13 & Hospitals/ primary health centers & \multicolumn{2}{|l}{} \\
\hline
\end{tabular}

Table.4.2 Distance of areas near by the Site

\begin{tabular}{c|l|c|}
\hline No. & \multicolumn{1}{|c|}{ Structures } & Distance from Site boundary \\
\hline 1. & House -1 & $25 \mathrm{mts}$ \\
\hline 2. & House -2 & $9 \mathrm{mts}$. \\
\hline 3. & State Highway - 159 & $42 \mathrm{mts}$. \\
\hline 4. & National Highway - & $147 \mathrm{mts}$. \\
\hline
\end{tabular}




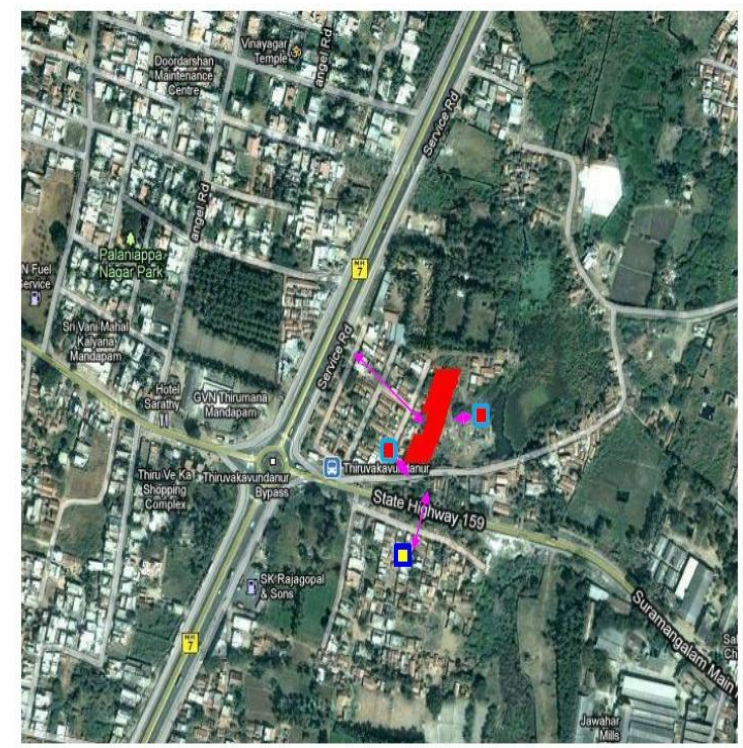

Fig no.4.2 Site Map showing nearby area

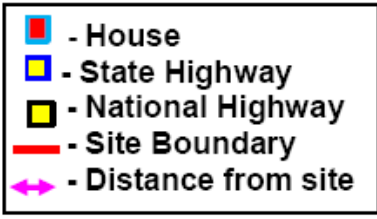

\section{METHODOLOGY}

Four Nos. of water samples were collected during the study period for Physicochemical and Bacteriological parameters after taking suitable precautions and analysed as per Standard methods. Samples were collected for Chemical analysis as per procedure outlined in IS: 3025:P1:2002. Sterilized bottles were used for collection of water samples for bacteriological analysis, stored in icebox and transported to the laboratory for the analysis. Parameters like $\mathrm{pH}$, Temperature, DO etc. were measured in the field while collecting the samples. MPN index of coliforms were determined in the laboratory as per Standard methods.

\subsection{Greenbelt Development}

\section{ENVIRONMENTAL MANAGEMENT PLAN:}

Eco-environment conservation and pollution abatement through greenbelt are two major components which are vital for any activity, whether proposed, existing or under expansion stage. Greenbelt development plan for a particular sector mainly depends upon:

i. Nature and extent of pollution load

ii. Sinking capacity of the ecosystem

iii. Climatic factors

iv. Soil and water quality

\section{CONCLUSION}

Identification, estimation/quantification of possible impacts over baseline status of water quality, biodiversity, terrestrial ecology, air quality, noise levels, flora and fauna at the proposed locations during the month of May 2011, reveals that:

[1] The proposed site is free of pollution sources.

[2] There are no critical habitats in the vicinity of the project locations.

[3] The project does not require clearing of any trees.

[4] There is no endemic and rare floral species are identified in the study area

[5] The aquatic environment will not have direct negative impact

The potential environmental, social and economic impacts of the project have been assessed and comprehensive mitigation and community developmental plans have also been developed. Environmental Management Plan will be exercised at design stage, construction stage and operational stage to meet all the 
consent norms of TNPCB With their expertise, experience, commitment and dedication, Salem City Municipal Corporation will Design, Construct, Commission and Operate the 35MLD capacity Sewage Treatment Plant (STP) - Fig.7.1. with modern technology at Mankuttai village in Salem Municipality of Salem district in Tamil Nadu.

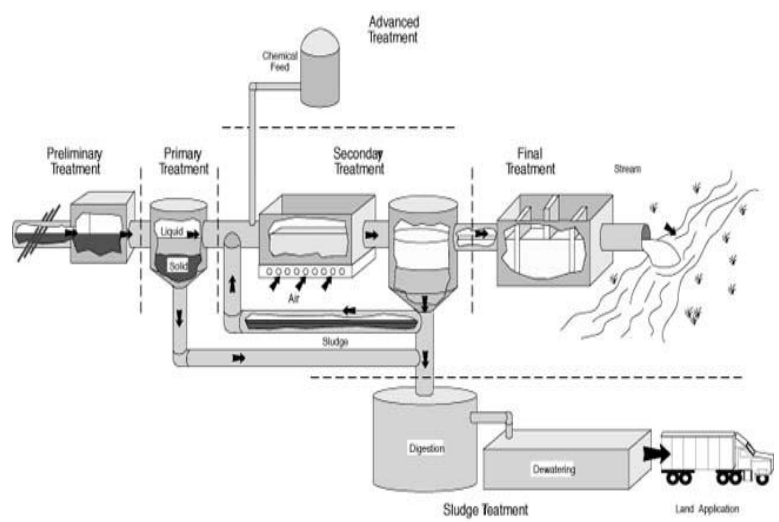

Fig.7.1 Modern Technology Sewage Treatment Plant (STP)

\section{REFERENCES}

[1]. Abteilung Abfallwirtschaft - Universität für Bodenkultur (ABF-BOKU) August 1997. Examination of Waste Sample Obtained from the Landfill Site Deir el- Balah - Gaza Strip; (Seive Size <25mm). Report.

[2]. ANRED. 1990. Sorting and Composting of Domestic Waste. ANRED Publication 27. France: ANRED.

[3]. Bardos, R. P., P. Hadley, and A. Kendle. 1992. Compost standards without tears: Some ideas from the UK, in Composting and Compost Quality Assurance Criteria, ed. V. Jackson, J-M Merillot, and P. L'Hermite, ed. Commission of the European Communities.

[4]. Subramani.T, Arulsankar.C Badrinarayanan.S, "Effect Of Sewage Farming On Ground Water", International Journal of Engineering Research and Applications, Volume. 4, Issue. 6 (Version 5), pp 163 - 172.

[5]. Bardos, R. P., P. Hadley, and A. Kendle. 1992. "Composting guidance in the United Kingdom.” Biocycle 33:6. Cited in Haug, R. T. 1993. The Practical Handbook of Compost Engineering. Boca Raton, Florida: Lewis Publishers.

[6]. Bidlingmaier, W. Autusm. 1993. "Odor emissions from composting plants." Compost Science and Utilization 1 (4):64-68.

[7]. Biocycle.1991. "The biocycle guide to the art and science of composting." Journal of Waste Recycling, The JG Press, Inc. Emmaus, Pennsylvania.

[8]. Briton, R. 1992. "German composting systems." Biocycle 33:6. Cited in Haug, R. T. 1993. The Practical Handbook of Compost Engineering. Boca Raton, Florida: Lewis Publishers.

[9]. Subramani.T , Mangaiyarkarasi.M , Kathirvel.C, “ Impact Of Sewage And Industrial Effluent On Soil Plant Health Act On Environment", International Journal of Engineering Research and Applications, Vol. 4, Issue 6( Version 2), pp.270-273, 2014. 